\title{
The Effects of $\mathrm{LaF}_{3}$ Coating on the Electrochemical Property of $\mathrm{Li}\left[\mathrm{Ni}_{0.3} \mathrm{Co}_{0.4} \mathrm{Mn}_{0.3}\right] \mathrm{O}_{2}$ Cathode Material
}

\author{
Su Hyun Yun, Seuk Buom Kim, and Yong Joon Park \\ Deparment of Advanced Materials Engineering, Kvonggi Lniversitw, Gveonggi-do $4+3-760$, Korea \\ ${ }^{\star}$ E-mail: ypark2006akionggi.ac.kr \\ Received June 3. 2009. Accepted September 9, 2009
}

\begin{abstract}
The effect of $\mathrm{LaF}_{3}$ coating on the structural and electrochemical properties of $\mathrm{Li}\left[\mathrm{Ni}_{0.3} \mathrm{Co}_{0.4} \mathrm{Mn}_{1.3}\right] \mathrm{O}_{2}$ cathodes was investigated using XRD, SEM, TEM, and a cycler. The coating layer consisted of nano-sized particles attached nonuniformly to the surface of pristine powder. Despite the surface coating treatment, phase difference by $\mathrm{LaF}_{3}$ coating was not detected. The discharge capacities of coated electrodes were a little lower than that of pristine sample at a I C rate. However, as the C rate increases, the capacity retention of the coated sample becomes obviously superior to that of the pristine sample. The cyclic performances of the electrodes in the voltage range of $4.8 \sim 3.0 \mathrm{~V}$ were also inproved by the surface coating. Such enhancement is attributed to the presence of the $\mathrm{LaF}_{3}$ coating layer, which effectively suppressd the reaction between electrodes and electrolytes on the surface of the Li[ $\mathrm{Ni}_{\mathrm{i}}, 3$ $\left.\mathrm{Co}_{0.4} \mathrm{Mn}_{0.3}\right] \mathrm{O}_{2}$ electrode.
\end{abstract}

Key Words: Surface coating. Electrochemical property. Cathode. Lithium battery

\section{Introduction}

Lithium ion batteries are representative system for electrochemical energy storage. At present. lithium ion batteries serve as an essential electric source for cellular phones, PDAs. and lap-top computers. Moreover. they have also been considered as a possible power source for new applications such as electric velicles (EVs). hybrid electric velicles (HEVs), and electric power tools. ${ }^{1-3}$ Cathode material is a key factor determining capacity, cyclic performance and thermal stability. Since the commercialization of lithium ion batteries. $\mathrm{LiCoO}_{2}$ has been used as a cathode material due to its stable property. However. to satisfy various needs of new application fields of lithium ion batteries, the introduction of new cathode materials having high capacity. long cycle life and low cost is inevitable. $\mathrm{Li}(\mathrm{Ni} . \mathrm{Co} . \mathrm{Mn}) \mathrm{O}_{2}$ is one of the most promising new cathode materials since its electrochemical properties are comparable or superior to other alternative cathode materials. ${ }^{4.5}$ However. this material has some problems such as inferior rate capability due to low electronic conductivity and the significant capacity fading during cycling was investigated when the upper cutoff voltage was increased to more than $4.6 \mathrm{~V}^{4,5}$ One approach to improve the electrochemical properties is to substitute transition metal ions for other elements such as $\mathrm{Mo} .{ }^{6} \mathrm{Cr}$, and $\mathrm{Zr}$. ${ }^{8}$ These elements may stabilize the layered structure. and prevent unwanted reactions between cathodes and electroly tes. Another way is to substitute fluorine for oxygen to stabilize the host structure. ${ }^{9-11}$ This method was also very effective for improving the cycling performance and themal stability of cathode materials. However. such approaches could cause a lowering of capacity and Li ion diffusion because the substituents are usually electrochemically inactive elements. In contrast. modifying the sufrace by coating it with stable oxides or phosphates is beneficial with respect to the delivery of the original capacity because there is no reduction of the amount of active elements in the parent structure. ${ }^{12-1 ?}$ One point we should consider is that the coating effect is highly dependent on the coating material. Cho et al. and Myung et al. reported that the electrochemical properties of coated cathode material is highly attributable to the coating materials themselves. ${ }^{16-1:}$ So the selection of good coating material is an important factor of coating treatments of cathode materials. Herein. lanthanum fluoride $\left(\mathrm{LaF}_{3}\right)$ was introduced as a coating material for $\mathrm{Li}\left[\mathrm{Ni}_{1}, \mathrm{CO}_{1}, \mathrm{Mn}_{13}\right] \mathrm{O}_{2}$ cathodes. A doping of $\mathrm{La}$ reportedly improved the discharge capacity and cyclic performance of the cathode, ${ }^{18}$ and lanthanum oxide coated cathode material has an excellent thermal stability and enhanced electrochemical properties. ${ }^{19.21}$ Moreover other fluoride such as $\mathrm{AlF}_{\text {; }}$ was successfully introduced as a coating material in various cathode materials. $^{\text {in }}$ In this work. we fabricated surface modified $\mathrm{Li}\left[\mathrm{Ni}_{3} \mathrm{CO}_{4} \mathrm{Mum}_{3}\right] \mathrm{O}_{2}$ cathodes with lanthanum fluoride $\left(\mathrm{LaF}_{3}\right)$. The morphology of coated powder and the electrochemical properties of coated electrodes were the focus of this study.

\section{Experimental}

The pristine $\mathrm{Li}\left[\mathrm{Ni}_{1.3} \mathrm{Co}_{1.4} \mathrm{Mn}_{1.2}\right] \mathrm{O}_{2}$ powder was a commercial product of Daejung Chenucals \& Metals. To prepare the coating solution. $\mathrm{La}\left(\mathrm{NO}_{3}\right)_{2} \cdot 6 \mathrm{H}_{2} \mathrm{O}(99.99$. Aldrich) and $\mathrm{NH}_{4} \mathrm{~F}$ (98+\%. Aldrich) were dissolved in distilled water, followed by continuous stirring for $2 \mathrm{~h}$ at $2 \mathrm{I}^{\circ} \mathrm{C}$. Subsequently. $\mathrm{Li}\left[\mathrm{Ni}_{1.3} \mathrm{Co}_{1.4} \mathrm{Mn}_{(1.2}\right] \mathrm{O}_{2}$ powder was added to the coating solution and mixed thorouglly for $2 \mathrm{~h}$ at $80^{\circ} \mathrm{C}$. The slurry was dried in an oven at $100^{\circ} \mathrm{C}$ for $12 \mathrm{~h}$ and heat-treated in a furnace at $400^{\circ} \mathrm{C}$ for $5 \mathrm{~h}$. The estimated concentration of $\mathrm{LaF}_{3}$ in the $\mathrm{Li}\left[\mathrm{Ni}_{1,2} \mathrm{CO}_{1} .4 \mathrm{Mn}_{(1.3}\right] \mathrm{O}_{2}$ powders was varied from 0.25 to $1.0 \mathrm{wt} \%$. $\mathrm{X}$-ray diffraction (XRD) patterns of powders were obtained using a Rigaku $\mathrm{X}$-ray diffractometer in the $2 \mathrm{q}$ range of $10^{\circ}$ to $70^{\circ}$ with monochromatized $\mathrm{Cu}-\mathrm{K}_{*}$ radiation $(\lambda=1.5406 \AA)$. The microstructure of the powder was observed using a field-emission scanning electron microscopy (FESEM. JEOLJSM 6500F). A transmission electron microscopy (TEM, 
JEOL-JEM 2100F) study was also carried out with an electron microscope. operating at $200 \mathrm{KV}$.

For electrochemical testing the cathode slurry was prepared by mixing the oxide powder. carbon black (Super P), and poly (viny lidene)fluoride (PVDF) at a weight ratio of 80:12:8. After 24 hr of ball mill processing, the viscous slurry was coated onto aluminum foil using a Dr. blade. and then dried at $90^{\circ} \mathrm{C}$ in an oven. The coin-type cell ( 2032 size) consists of a cathode. a Li metal anode, a separator. and an electroly te. The electrolyte was $1 \mathrm{M} \mathrm{LiPF}_{6}$ with ethylene carbonate/dimethyl carbonate (EC/DMC) (1:1 vol\%). Cells were subjected to galvanostatic cycling using a WonAtech sy'stem in the voltage range of $4.6 \sim 3.0 \mathrm{~V}$ at various rates between $1 \sim 12 \mathrm{C}$, and in the voltage range of $4.8 \sim 3.0 \mathrm{~V}$ at $\mathrm{I} \mathrm{C}$ rates.

\section{Results and Discussion}

Figure 1 presents scanning electron microscopy (SEM) images of the $\mathrm{Li}\left[\mathrm{Ni}_{3,3} \mathrm{CO}_{0,4} \mathrm{Mn}_{3,3}\right] \mathrm{O}_{2}$ powders. In all the cases. the $\mathrm{Li}\left[\mathrm{Ni}_{1.3} \mathrm{Co}_{0.1}, \mathrm{Mn}_{;}, 3\right] \mathrm{O}_{2}$ powders display sphere shapes of approximately $8-12 \mu \mathrm{m}$. The particles are composed of smooth-edged $0.5 \sim 1.0 \mu \mathrm{m}$ sized polyhedral primary particles. At low magnification. no significant difference was observed between the coated and uncoated samples. However. at higher magnification. it is revealed that the roughness of the surface increases slightly beculase of the reaction of the primary particles with nanoparticles. As the amount of $\mathrm{LaF}_{3}$ coating increased, nano-particles developed on the surface of the coated sample.

The shape of the primary praticles and the surface morphology' was investigated in detail transmission by electron microscopy (TEM) analysis. Figure 2 shows the TEM images of the pristine and $0.5 \mathrm{wt} \%$ coated $\mathrm{Li}\left[\mathrm{Ni}_{3} \mathrm{CO}_{i_{1}} \mathrm{Mnh}_{3}\right] \mathrm{O}_{2}$ pow-
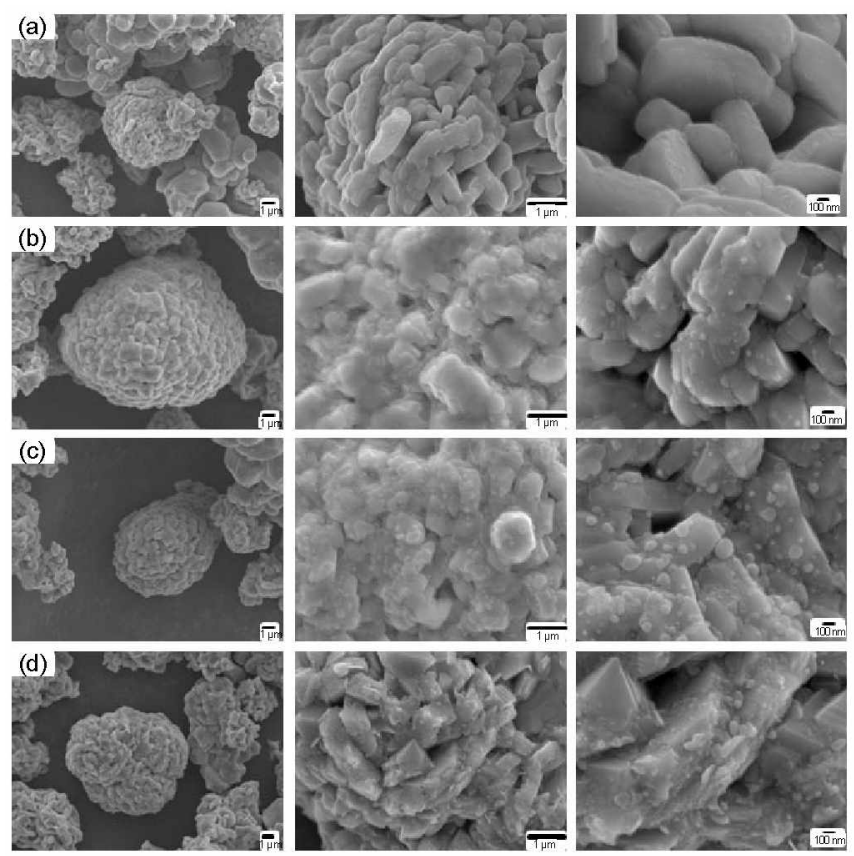

Figure 1. SEM images of (a) Pristine; (b) $0.25 \mathrm{wt} \%$, (c) $0.5 \mathrm{wt} \%$, (d) $1.0 \mathrm{wt} \% \mathrm{LaF}_{3}$ coated $\mathrm{Li}\left[\mathrm{Ni}_{0.2} \mathrm{Co}_{0.4} \mathrm{Mn}_{0.2}\right] \mathrm{O}_{2}$ cathode. ders. The pristine sample particles exhibit a smooth surface, whereas. the surfaces of the $0.5 \mathrm{wt} \%$ coated $\mathrm{Li}\left[\mathrm{Ni}_{3}, \mathrm{Co}_{i}, 4\right.$ $\left.\mathrm{Mn}_{(1.3}\right] \mathrm{O}_{2}$ particle are covered with a coating layer. Most of the coating layer comprised nano-structured particles of diameter $100 \sim 200 \mathrm{~nm}$. but some parts of it comprised homogeneous film. EDX analysis (the data are omitted) indicates the existence of $\mathrm{La}$ and $\mathrm{F}$ on the surface of the coated samples. The SEM. TEM and EDX results confirm that the coating layer was successfully formed on the surface of the coated $\mathrm{Li}[\mathrm{Ni}$, $\mathrm{Co}_{0.4} \mathrm{Mn}_{0.1 .2} \mid \mathrm{O}_{2}$ powders.

Figure 3 shows the X-ray diffraction (XRD) patterns of pristine and $\mathrm{LaF}_{3}$ coated $\mathrm{Li}\left[\mathrm{Ni}_{(3.3} \mathrm{CO}_{1 .} \mathrm{Mn}_{3.3}\right] \mathrm{O}_{2}$ powders. The diffraction patterns of all the samples are indexed well with that of a typical layered structure with an $R \overline{3} \boldsymbol{m}$ space group. The phases of the coated samples were identical to that of a pristine saniple. The unique change in the phase caused by the $\mathrm{LaF}_{3}$ coating was not revealed in the diffraction pattern. This indicates that the surface coating layer was formed as an amorphous phase. The coating sources were heat-treated at $400^{\circ} \mathrm{C}$, which is not high enough for the formation of a crystalline coating phase. It las also been reported that most of the coating layers were amorphous. ${ }^{12-1 \text { ? }}$ In fact. glassy coating layers are expected to facilitate $\mathrm{Li}$ ions transport across the surface because of their open structure. However. the coating layer with a crystalline phase also enhanced the electrochemical properties and the thennal stability of cathode materials. as shown in our previous study

The electrochemical properties of the pristine and coated $\mathrm{Li}\left[\mathrm{Ni}_{1,3} \mathrm{Co}_{1,4} \mathrm{Mn}_{0.1 .2}\right] \mathrm{O}_{2}$ electrodes were determined to investigate the coating effect on the capacity, cyclic performance, and rate capability of the electrodes. Figure 4 shows the discharge capacities of the pristine and coated $\mathrm{Li}\left[\mathrm{Ni}_{1,3} \mathrm{CO}_{0.4}\right.$ $\left.\mathrm{Mn}_{13}\right] \mathrm{O}_{2}$ electrodes at $1 \mathrm{C}, 2 \mathrm{C} .+\mathrm{C}, 6 \mathrm{C}, 8 \mathrm{C}, 10 \mathrm{C}$ and $12 \mathrm{C}$

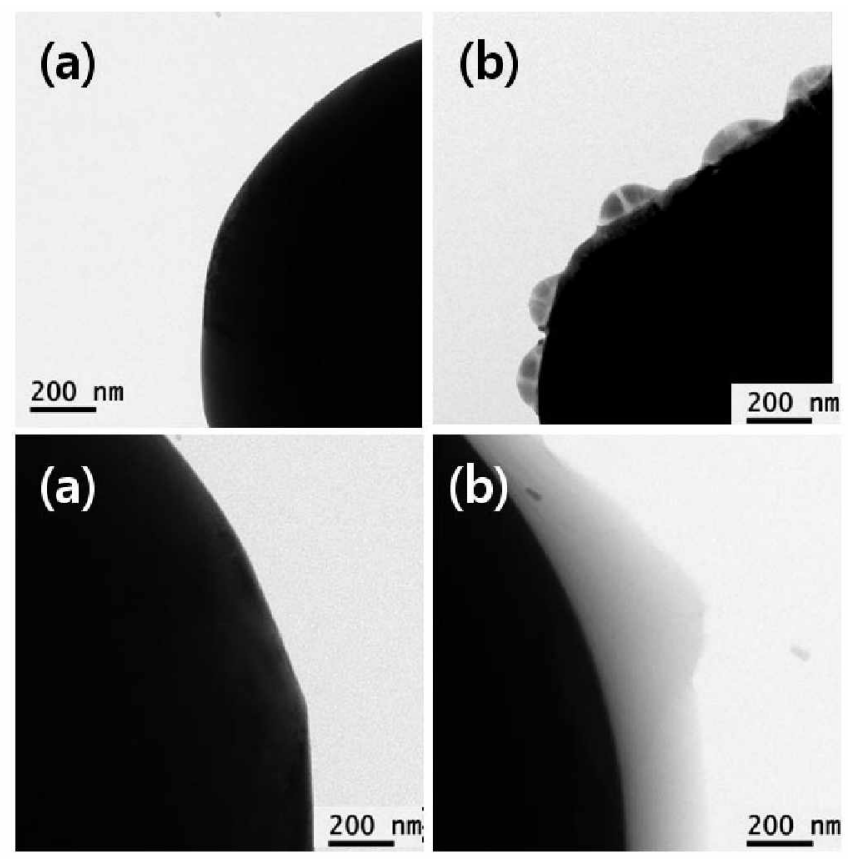

Figure 2. TEM images of (a) Pristine; (b) $0.5 \mathrm{wt} \% \mathrm{LaF}_{3}$ coated $\mathrm{Li}\left[\mathrm{Ni}_{0.3} \mathrm{Co}_{0 .+} \mathrm{Mrl}_{0.3}\right] \mathrm{O}_{2}$ cathode. 


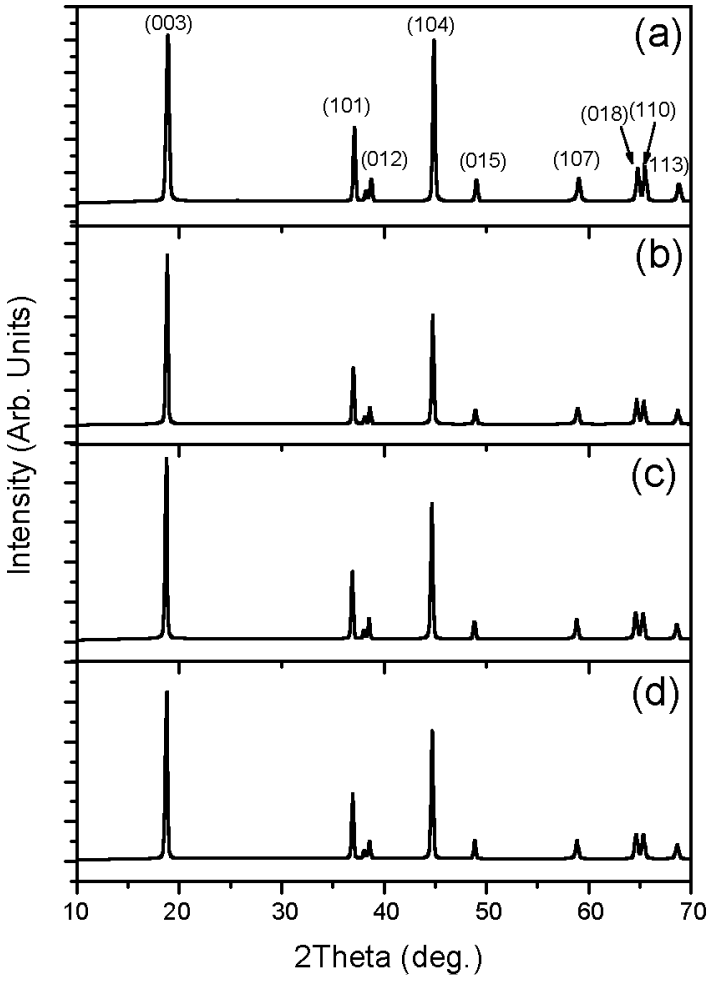

Figure 3. XRD pattems of (a) Pristine; (b) $0.25 \mathrm{wt} \%$, (c) 0.5 wt $\%$, (d) 1.0 wt $\% \mathrm{LaF}_{3}$ coated $\mathrm{Li}\left[\mathrm{Ni}_{3}, \mathrm{Co}_{1}, \mathrm{Mi}_{3}, 3 \mathrm{O}_{2}\right.$ cathode.

rates in the voltage range $4.6 \sim 3.0 \mathrm{~V}$. The discharge capacity of the pristine sample was slightly higher than that of the coated sample over several initial cycles at a $1 \mathrm{C}$ rate. However. as the $\mathrm{C}$ rate increased, the discharge capacity of the pristine sample rapidly decreased. In contrast. while the discharge capacity of the coated samples was inferior at $1 \mathrm{C}$ rate, the decrease in the discharge capacity at high $C$ rates was relatively lesser. This means that the rate capability of the coated samples is superior to that of the pristine sample. Table 1 summarizes the discharge capacity and capacity retention at various $C$ rates (the values of the first cycle). From the table. it is apparent that the ratio of the discharge capacity at a high $\mathrm{C}$ rate to that at a $1 \mathrm{C}$ rate was enhanced by coating treatment. For a pristine electrode, the capacity retention at a $12 \mathrm{C}$ rate was only $16.7 \%$ that at a $\mathrm{I} \mathrm{C}$ rate. In contrast. the capacity retentions were $28.8 \%, 22.0 \%$. and $23.8 \%$ for samples coated with $0.25 \mathrm{wt} \%$,

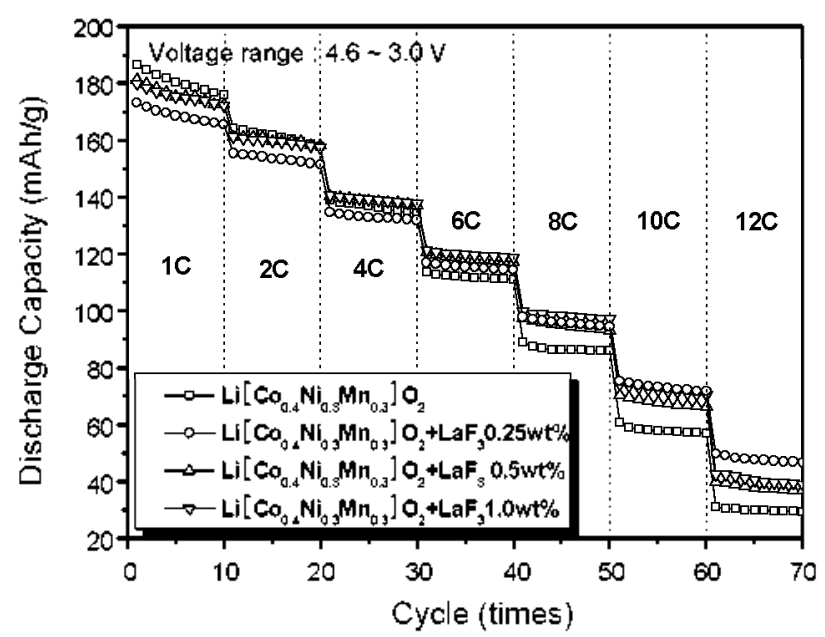

Figure 4. Discharge capacities and cyclic performances of pristine and coated $\mathrm{Li}\left[\mathrm{Ni}_{3} \mathrm{CO}_{0} \mathrm{Mn}_{0}\right] \mathrm{O}_{2}$ electrode in the voltage range of $4.6 \sim 3.0 \mathrm{~V}$ at $1,2,4,6,8$ and $12 \mathrm{C}$ rates

$0.5 w t \% .1 .0 w t \%$. respectively. Figure 5 shows the initial discharge profiles of the pristine and coated electrodes at $8 \mathrm{C}$ and $12 \mathrm{C}$ rates. The discharge capacities of the pristine electrode were just $89 \mathrm{mAl} / \mathrm{g}$ ( $8 \mathrm{C}$ rate) and $3 \mathrm{l} \mathrm{mAh/g} \mathrm{(} 12 \mathrm{C}$ rate). respectively. However, the capacity was enhanced by surface coating. A sample coated with $0.25 \mathrm{wt} \% \mathrm{LaF}_{3}$ delivered a higher discharge capacity of $97 \mathrm{mAl} / \mathrm{g}(8 \mathrm{C}$ rate $)$ and $50 \mathrm{mAh} / \mathrm{g}$ (12 $\mathrm{C}$ rate). The effect of surface coating on the rate capability was more clearly observed as the $\mathrm{C}$ rate increased. Electrodes coated 0.5 and $1 w t \% \mathrm{LaF}_{3}$ also showed improved discharge capacities. although the improvements were slightly smaller than the improvement in the case of the sample coated with $0.25 \mathrm{wt} \%$. These results prove that the $\mathrm{LaF}_{3}$ coating can effectively enhance the rate capability of a $\mathrm{Li}\left[\mathrm{Ni}_{(1.3} \mathrm{CO}_{(1.4} \mathrm{Mn}_{3.3}\right] \mathrm{O}_{2}$ electrode. The coating material can protect the core material from direct contact with the acidic electrolyte when the cells are clarged to their lighest potentials. ${ }^{23.24}$ Myung et al proposed a possible explanation for the improvement of battery performance by metal oxide coating. ${ }^{126}$ They reported that the metal oxide coating layer transformed to a metal fluoride layer during cycling. This is highly effective for offering protection against HF attacks during cycling. Since the metal fluoride layer formed by reactions with $\mathrm{HF}$ in the electrolyte can serve as a protecting layer. direct coating with metal

Table 1. Discharge capacities and capacity retentions of $\mathrm{Li}\left[\mathrm{Ni}_{1} ; \mathrm{Co}_{0}{ }_{4} \mathrm{Mn}_{0}\right] \mathrm{O}_{2}$ samples at various $\mathrm{C}$ rates (values of the first cyclej. (\%) means capacity retention compared to the discharge capacity at $\mathrm{l} C$ rate.

\begin{tabular}{|c|c|c|c|c|c|c|c|c|}
\hline & $\begin{array}{l}\text { Pristine } \\
(\mathrm{mAl} / \mathrm{g})\end{array}$ & $(\%)$ & $\begin{array}{c}\mathrm{LaF}_{3} 0.25 \mathrm{wt} \% \\
(\mathrm{mAh} / \mathrm{g})\end{array}$ & $(\%)$ & $\begin{array}{c}\mathrm{LaF}_{3} 0.5 \mathrm{wt} \% \\
(\mathrm{mLl} / \mathrm{g})\end{array}$ & $(\%)$ & $\begin{array}{c}\mathrm{LaF}_{3} 1.0 \mathrm{wt} \% \\
(\mathrm{mAl} / \mathrm{g})\end{array}$ & $(\%)$ \\
\hline $1 \mathrm{C}$ & 186.46 & 1000 & 172.97 & 1000 & 181.03 & 1000 & 179.74 & 100.0 \\
\hline $2 \mathrm{C}$ & 164.02 & 88.0 & 155.32 & 89.8 & 160.92 & 88.9 & 161.06 & 89.6 \\
\hline $4 \mathrm{C}$ & 138.64 & 74.4 & 134.65 & 77.8 & 140.14 & 77.4 & 140.57 & 78.2 \\
\hline $6 \mathrm{C}$ & 113.75 & 61.0 & 116.86 & 67.6 & 120.53 & 66.6 & 121.13 & 67.4 \\
\hline $8 \mathrm{C}$ & 88.95 & 47.7 & 97.73 & 56.5 & 97.50 & 53.9 & 99.83 & 55.5 \\
\hline $10 \mathrm{C}$ & 60.78 & 32.6 & 75.31 & 43.5 & 70.35 & 38.9 & 74.31 & 41.3 \\
\hline $12 \mathrm{C}$ & 31.15 & 16.7 & 49.81 & 28.8 & 39.89 & 220 & 42.71 & 23.8 \\
\hline
\end{tabular}



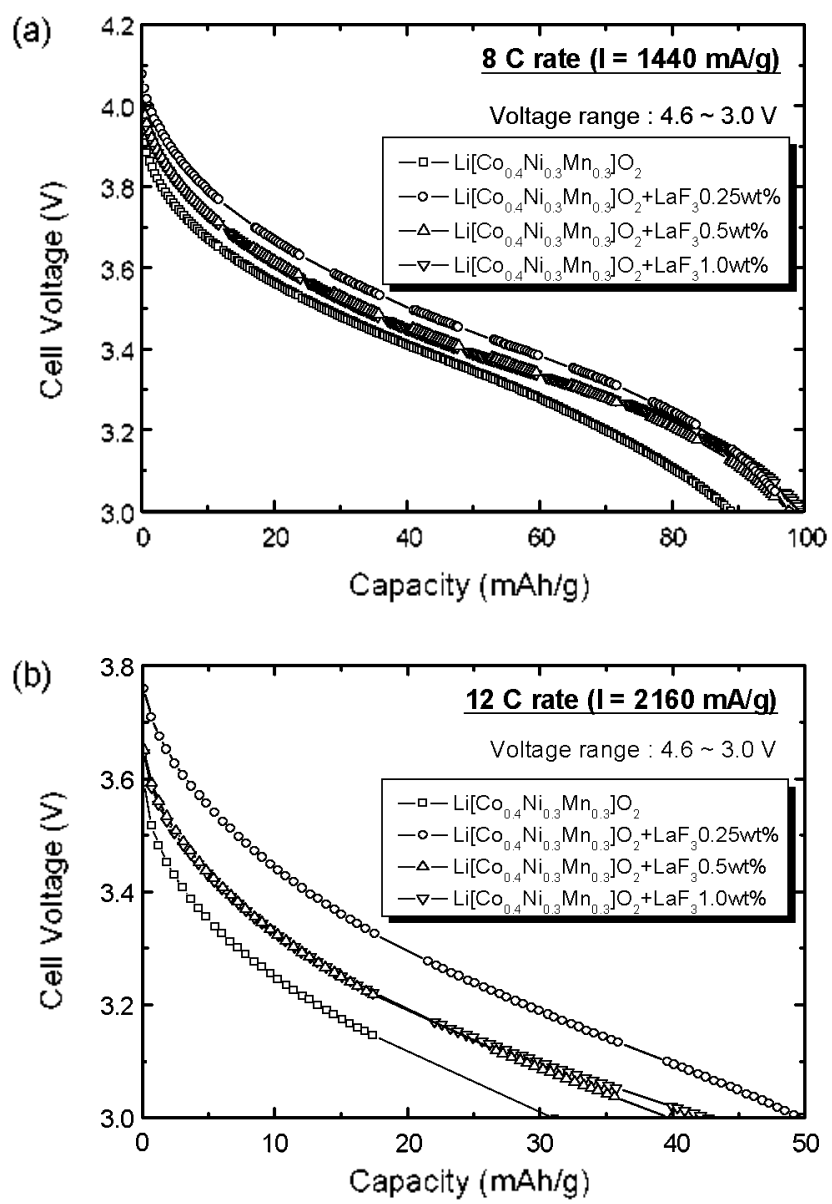

Figure 5. Initial discharge profiles of pristine and $\mathrm{LaF}_{3}$ coated $\mathrm{Li}\left[\mathrm{Ni}_{1}, \mathrm{CO}_{1}, \mathrm{Mrl}_{3}\right] \mathrm{O}_{2}$ electrodes in the voltage range of $4.6 \sim 3.0 \mathrm{~V}$ at (a) $8 \mathrm{C}$ rate and (b) $12 \mathrm{C}$ rate.

fluorides such as $\mathrm{LaF}_{3}$ can have a superior effect on the surface protection achieved by the presence of $\mathrm{HF}$ in the electrolytes. Therefore. undesired reactions between electrodes and elecrolytes are likely to be suppressed by $\mathrm{LaF}_{3}$ coating treatment.

All of the pristine and coated electrodes presented good cyclic behavior in the voltage range $4.6 \sim 3.0 \mathrm{~V}$. However. the significant capacity degradation during cycling was investigated by increasing the upper cutoff voltage over 4.6 V. Figure 6 shows the cycling behavior of the pristine and coated $\mathrm{Li}\left[\mathrm{Ni}_{3} 3\right.$

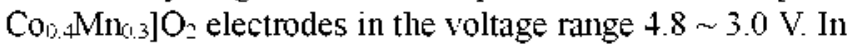
order to clearly illustrate the effect of the $\mathrm{LaF}_{3}$ coating on the cycling behavior. the upper cut-off voltage was increased to 4.8 V. As mentioned earlier. the discharge capacity of the pristine sample was rapidly decreased during cycling. But the cyclic performance of the coated electrode was slightly enhanced. The electrode charged to high voltages is vulnerable because the reactions between the surfaces of the electrode and the electrolyte are activated. That is why the capacity fades rapidly when the cut-off voltage increases above 4.6 V. However, if a stable surface layer is formed by $\mathrm{LaF}_{3}$ coating treatment. surface reactions can be retarded. and thus. the cyclic performance can be improved. However the capacity fading of the coated samples was still rapid. therefore. in future studies. coated samples must be used at cut-off voltages

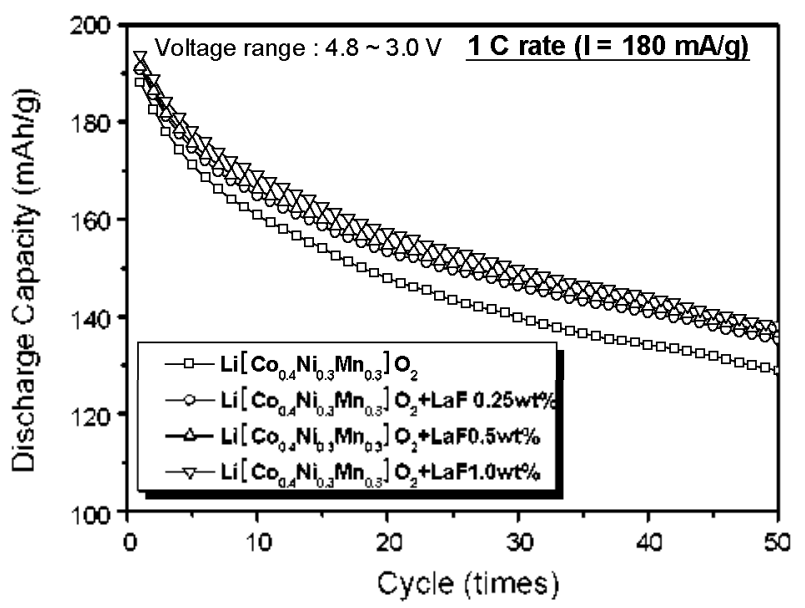

Figure 6. Cyclic performance of pristine and $\mathrm{LaF}_{3}$ coated $\mathrm{Li}\left[\mathrm{Ni}_{0.3}\right.$ $\mathrm{Co}\left(14 \mathrm{Mn}_{03}\right] \mathrm{O}_{2}$ electrode in the voltage range of $4.8-3.0 \mathrm{~V}$ at a rate of $1 \mathrm{C}$ (specific current $=180 \mathrm{mAhg}^{-1}$ ).

higher than $4.6 \mathrm{~V}$.

\section{Conclusions}

The surface of a conmercial $\mathrm{Li}\left[\mathrm{Ni}_{3} \mathrm{CO}_{4} \mathrm{Mni}_{3}\right] \mathrm{O}_{2}$ cathode was modified with $\mathrm{LaF}_{3}$ coating. The XRD patterns of the coated materials did not show any extraneous peaks corresponding to the coated particles. However the rough surface of a coated sample comprising nano-particles with diameters $100-200 \mathrm{~mm}$. and an EDX analysis results indicating the existence of $\mathrm{La}$ and $\mathrm{F}$ on the surface suggested that the coating layer was succesfully formed. Galvanostatic charge-discharge studies at various $\mathrm{C}$ rates showed that $\mathrm{a} \mathrm{LaF}_{2}$ coating enhanced the rate capability and cyclic performances of the electrodes. Such enhancement is due to the presence of a stable $\mathrm{LaF}_{3}$ coating layer. which effectively suppressed the reactions between electrodes and electrolytes on the surface electrode.

Aclonowledgments. The work was carried out with financial support from the 2007 Kyonggi-University specialization progrant.

\section{Refeiences}

1. Zhang, S.; Qiu, X.; He, Z; Weng, D.; Zhu, W. J. Power Sources $2006,153,350$

2. Amine, K.; Lill, I.; Belharouak, I.; Kang, S. H.; Bloom, I.; Vissers, D.; Henriksen, G. J. Power Soutes 2005, 146, 111 .

3. Park, Y. J.; Lee, J. W.; Lee, Y.-G.; Kim, K. M.; Kang, M. G.; Lee, Y. Bull Korean Chem Soc. 2007, 28, 2226

4. Yabuuchi, N.; Makimura, Y:; Olzuku, T. J. Electrochem. Soc. 2007,154, A 314

5. Choi, T. Manthiram, A. J. Electrochent. Soc 2005, 152, A1714.

6. Wang, L. Q.; Jiao, L. F.; Yuan, H. T.; Guo, T.: Zhao, M.: Li, H. X: Wang, Y. M. J. Power Sonces 2006, $162,1367$.

7. Guo, J.: Jiao, L. F.: Yuan, H. T.; Wang. L. Q.: Li, H. X.: Zhang, M.: Wang, Y. M. Electrochint Acta 2006, 51, 6275.

8. Lin, B.; Wen, Z; Gu, Z; Xu, X. J. Power Soures 2007, 17 . $5+4$.

9. Kim, G.-H.: Kim, M.-H.: Myung, S.-T.: Sun, Y. K. J. Power Soltres 2005, $1+16,602$.

10. Kim, G.-H.; Kim, J.-H.; Myung, S.-T.; Yoon, C. S.; Sun, Y.-K. J. Electrochem. Soc. 2005, 152, A1707. 
11. Liao, L.: Wang, X.: Luo, X.: Wang, X:; Ganboa, S; Sebastian, P. J. J. Power Sources 2006, $160,657$.

12. Myung, S.-T.: Izumni, K, Komaba, S.; Sun, Y.-K.: Yashiro, H.: Kumagai, N. Chem. Water, 2005, 17, 3695.

13. Cho, J.; Kim, Y. T.; Kim, T.-J.; Park, B. Angew: Chent. Int. Ed. Engl. 2001, 10, 3367.

14. Cho, I: Kim, Y. J.: Park, B. Chem. Mater. 2000, 12, 3788

15. Thackeray, M. M.; Tolunson, C. S.; Kim, J. S.; Lauzze, K. C.; Vaugher, I. T.; Dietz, N.; Abraham, D; Hackney, S. A.; Zeltner, W.: Anderson, M. A. Electrochem. Commm. 2003, 5, 752 .

16. Myung, S.-T.: Izuni, K.; Komaba, S.; Yashiro, H.: Bang, H. J.: Sun, Y. K.; Kumagai, N. J. Phys. Chem. 2007, C111, 4061 .

17. Lee, H.; Kim, Y : Hong, Y. S : Kim, Y.; Kim, M. G.; Shin, N.-S. Cho, T. J. Electrochem. Soc. 2006, 153, A781.
18. Ding. Y.; Zhang, P., Jiang. Y.: Gao, D. Solid State Ionics 2007. 178,967

19. Fey, G. T.; Muralidharan, P.; Lu, C.-Z.; Cho, Y. D. Electrochim. Acto 2006, 51,4850

20. Ryu, J. H.: Kim, S. B.; Park. Y. T. Bull. Konen Chem. Soc. 2009, 30,657 .

21. Park, B.-C.: Kim, H.-B.; Mylung, S.-T.; Amine, K.: Belharouak, I.; Lee, S.-M.; Sun, Y. K. J. Power Solmes 2008, 178, 826.

22. Sun, Y. K: Cho, S.-W: Lee, S.-W; Yoon, C. S.; Amine, K. $J$. Electrochem. Soc. 2007, 157, A168.

23. Chen, Z; Dahn, I. R. Electrochim. Acta 2004, 19, 1079.

24. Cho, J-; Kim, T.-G.; Kim, C; Lee, J.-G.; Kim, Y.-W ; Park, B. J. Power Sonces 2005, 1 t6, 58

25. Choi, T, Manthiram, A. J. Electrochem Soc. 2005, 152, Al714. 